\title{
The Role of Agricultural Radio Programs in the Adoption of Agricultural Technologies among Famers in Girei Local Government Area of Adamawa State, Nigeria
}

\author{
${ }^{1}$ Maurice David Chinda (Ph.D), ${ }^{2}$ Ali SalamatuShuwa and ${ }^{\mathbf{1}}$ Ali Yagana \\ ${ }^{1}$ Department of Agricultural Economics and Extension, ModibboAdama University of Technology, Yola, \\ Adamawa Nigeria \\ ${ }^{2}$ Department of Agricultural Technology, Adamawa State Polytechnic, Yola, Adamawa, Nigeria
}

\begin{abstract}
The study examined the role of agricultural radio programs in the adoption of agricultural production technologies among farmers in Girei Local Government of Adamawa State. Primary data was used for the study and were collected from a random selection of 113 farmers in ten villages randomly selected for the study. The data were analyzed using both descriptive (frequency counts, percentages and means) and inferential statistics (multiple regression analysis). Results show that most of the respondents were male (69.9\%), had some levels of formal education (61.1\%) and with an average age of 34 years. Many of the respondents were aware of agricultural programs aired on radio in the area, especially agricultural programs aired on Gotel FM (80.5\%) and Adamawa Broadcasting Corporation (63.7\%). The common agricultural programmes aired on radio among others include producing marketing (89.4\%), fish production (77.9\%), poultry disease control (77.7\%) and planting methods (70.8\%). On the information needs of the farmers, the study identified mostly crop production-related information needs as the one most needed by the farmers. On the factors responsible for the adoption of agricultural technologies aired on radio, the study identified the age of the farmers (x1), education (x2), farm size (x5) and radio ownership (x10) as significantly influencing the adoption of agricultural production technologies aired on radio in the area. The study recommended the need for farmers to have some level of formal education to enable them to make better use of any technology aired on radio and that the radio stations should give more slots to agricultural programs so as to create awareness for farmers.
\end{abstract}

Keywords: Agriculture, Adoption, Girie, Technologies, Technology adoption, Radio programme.

\section{INTRODUCTION}

The need for farmers to adopt agricultural innovation has been pursued with zeal by policy makers, government and research institutions due to the global effect of climate change. Agricultural innovations are known to be important in enhancing and improving agricultural production among farmers in every nation. Agriculture is increasingly becoming information sensitive; hence access to information has become a pre-requisite and a valuable resource for agricultural and rural development [1]. In this context, information is needed to exploit opportunities in time, raise awareness about the potential negative impacts of current choices and to get to know about opportunities of other farmers, in order to search for better opportunities and sustainable solutions [2]. 
In Nigeria, one way by which the agricultural sector can be developed is for farmers to have access to agricultural technologies. The development of these technologies requires among other things, a timely and systematic transmission of useful and relevant agricultural information (messages) through relatively well educated technology dissemination (extension) from formal technology generation system (research) via various communication media (channels) to the intended audience - farmers [3]. If farmers have adequate access to, and adopt agricultural innovation, the problem of food shortages would be minimized. Communication has been acknowledged to play a prominent role in the success of agricultural production and adoption of innovations through programmes aired. Effective communication can help facilitate mutual understanding among farmers, agricultural scientist and extension workers [4]. According to [5], good information improves decision-making, enhances efficiency and provides a competitive edge. Information is a critical resource in the operation and management of the agricultural enterprise [6]

Mass media offer effective channels for communicating agricultural messages, which can increase knowledge and influence behavior of audience members. Various communication media are used in transmitting agricultural information to farmers. Some of these include; farm magazine, leaflets, newsletters, newspapers, pamphlets, radio and television among others. Of these sources Broadcast media (radio) are usually cheaper, faster, and capable of disseminating information to large audiences efficiently irrespective of their locations, socio-economic characteristics, topography and distance so long as people have a receiver with adequate supply of power [7]. Broadcast media as powerful communication tools have proved to be the most effective media in promoting agriculture and development in rural areas which is a tool for the delivery of quick information [8].Illiteracy is no barrier to radio messages since such messages can be passed in the audience's own language. It is probably because of these advantages that many media outfits accord high priority to radio programmes as a means of reaching farmers.

The need to maximize economic returns and improve general welfare has been the driving force behind technology adoption by farmers. Reference [9] and [10] identified the problems of agricultural information or communication in Nigeria to include among others poor reception quality, messages carried are not tailored to the information needs of rural populations; even when information is relevant, it is seldom aired at the proper time and so does not get to the targeted audience and technical language used in communicating information is incomprehensible to the farmers. If agricultural radio programmes are properly blended with other modes of promoting agricultural development, it would bring about increase in productivity. There seem to be a gap between agricultural research result and the farm users. A lot of research results are seldom used by farmers either because such information did not reach them, or because the implementation of the information is not clear. Against this backdrop, this study intends to assess the role of radio programmes in the adoption of agricultural technologies among farmers in Girei Local Government Area of Adamawa State.

\section{STUDY AREA}

Girei Local Government Area of Adamawa State is located between Latitude $9^{0} 11$ and $9^{0} 39^{1}$ North and Longitude $12^{0}$ 11 and $12^{\circ} 49$ East of the equator [11].The area has land mass of about 2186sqkm and has a population of 129,995 people [12]. It shares common boundaries with Song Local Government to the north, Fufore Local Government to the east, and Yola North, ,Demsa and Yola South Local Governments to the south. The Local Government comprise has only one district and ten political wards, namely; GireiOne, GireiTwo, Moddire, Jera-Bonyo, Jera-Bakari, Gereng, Tambo, Dakri and Damare.

Thearea has a tropical climate marked by distinct rainy and dry seasons. The average rainfall is about 792mm [11]. The vegetation of the area is Sudan Savannah characterized by light forest in the area. The main occupation of the people in the area is farming and animal rearing. There are also civil servants and small scale traders. The major ethnic groups found in the area are Fulani, Hausa and Bata. Its closeness to the state capital provide advantage of market for agricultural produce. The major crops cultivated in the area are sorghum, maize, cowpea, rice and groundnut. 


\section{MATERIALS AND METHOD}

Multi-stage random sampling technique was used in selecting respondents for the study. First stage sampling involved the random selection of five (5) out of the ten (10) wards in the Local Government Area. From each of the selected wards, two (2) villages were randomly selected to give a total number of sampled villages to ten (10). One hundred and thirteen (113) farmers were randomly selected in the selected villages in proportion to the size of villages.

\section{DATA ANALYSIS}

Both descriptive and inferential statistics were used in analysing the data collected. Descriptive statistics involved the use of frequency counts and percentages. Inferential statistics involved the use of multiple regression analysis to determine the factors influencing the adoption of agricultural production technologies airedon radio stations by farmers.

The explicit form of the model is specified as:

$\mathrm{Y}=\mathrm{f}\left(\mathrm{X}_{1}, \mathrm{X}_{2}, \mathrm{X}_{3}, \mathrm{X}_{4}, \mathrm{X}_{5}, \mathrm{X}_{6}, \mathrm{X}_{7}, \mathrm{X}_{8}, \mathrm{X}_{9}, \mathrm{X}_{10}\right)$

Where

$\mathrm{Y}=$ Adoption index (number of technologies adopted by the respondents),

$\mathrm{X}_{1}=$ Age of farmers (in years),

$\mathrm{X}_{2}=$ Level of formal education (number of years spent in school),

$\mathrm{X}_{3}=$ Household size (number of people in household),

$\mathrm{X}_{4}=$ Farming experience (in years),

$\mathrm{X}_{5}=$ Farm size (in hectares),

$\mathrm{X}_{6}=$ Extension contact (number of visits),

$\mathrm{X}_{7}=$ Gender ( 1 for male respondents and 2 for female respondents),

$\mathrm{X}_{8}=$ Credit access (dummy where $1=$ access to credit; and $0=$ otherwise),

$\mathrm{X}_{9}=$ Membership of farmers' organization (dummy, where $1=$ membership of a cooperative or farmer group; 0 otherwise)

$\mathrm{X}_{10}=$ Radio ownership (dummy, where1 respondent owned a radio; 0 other wise)

\section{RESULTS AND DISCUSSIONS}

\subsection{Socio-economic Characteristics of Respondents}

The socioeconomics of the respondents are presented in Table 1. The sex distribution of respondents indicates that majority $(69.9 \%)$ of the respondents were male while female constituted $30.1 \%$. This indicates that male farmers were more in the area than female farmers. Their marital status indicates that majority (71.7\%) were married, an indication that most of the respondents are household heads.

The age distribution indicates that the respondents' mean age was estimated at 34 years, an indication that they are strong and are in their economically active age [13]. This group is most likely active in farming and tends to develop more interest in sourcing for agricultural technology through the mass media. The average household size in the area was estimated at 8 , an indication of a fairly large household. Listening to agricultural programmes on radio will be more among farming households than non-farming households especially if the programmes have the potential of raising productivity and household incomes. This agrees with the assertion by [14] who stated that larger household size is an advantage in the adoption of increased technologies.

The distribution of the educational levels of the respondents indicates that literacy level among them is high (61.1\%); hence, a greater number of them would find it easy to perceive, interpret and respond to new information much faster than their counterparts without education. More educated farmers are typically assumed to be better able to process information and search for appropriate technologies from various sources to alleviate their production constraints. On their farm sizes, the mean farm size 
among the respondents was estimated at 2.54ha, an indication that they are mostly small-scaled farmers. Most (76.1\%) of the respondents had contacts with extension agents at different times in the last cropping season.

Table 1: Socio-Economic Characteristics of the Respondents

\begin{tabular}{|c|c|c|c|}
\hline Variables & Frequency $(n=113)$ & Percentage & Mean \\
\hline \multicolumn{4}{|l|}{ Sex } \\
\hline Male & 79 & 69.9 & \\
\hline Female & 34 & 30.1 & \\
\hline \multicolumn{4}{|l|}{ Marital status } \\
\hline Single & 27 & 23.9 & \\
\hline Married & 81 & 71.7 & \\
\hline Divorced & 2 & 1.8 & \\
\hline Widow/er & 3 & 2.7 & \\
\hline \multicolumn{4}{|l|}{ Age (years) } \\
\hline $20-29$ & 39 & 34.5 & \\
\hline $30-39$ & 33 & 29.2 & 34.46 \\
\hline $40-49$ & 26 & 23.0 & \\
\hline $50-59$ & 12 & 10.6 & \\
\hline$\geq 60$ & 3 & 2.7 & \\
\hline \multicolumn{4}{|l|}{ Household Size } \\
\hline $1-5$ & 39 & 34.5 & \\
\hline $6-10$ & 42 & 37.2 & 8.11 \\
\hline $11-15$ & 28 & 24.8 & \\
\hline$\geq 16$ & 4 & 3.5 & \\
\hline \multicolumn{4}{|l|}{ Educational Level } \\
\hline No formal education & 44 & 38.9 & \\
\hline Primary education & 21 & 18.6 & \\
\hline Secondary education & 29 & 25.7 & \\
\hline Tertiary education & 19 & 16.8 & \\
\hline \multicolumn{4}{|l|}{ Farm Size (ha) } \\
\hline$\leq 2.0$ & 68 & 60.2 & \\
\hline $2.1-3.9$ & 18 & 15.9 & 2.54 \\
\hline $4.0-5.9$ & 24 & 21.2 & \\
\hline$\geq 6.0$ & 3 & 2.7 & \\
\hline \multicolumn{4}{|l|}{ Extension Contact } \\
\hline Non & 27 & 23.9 & \\
\hline Once yearly & 12 & 10.6 & \\
\hline Twice yearly & 23 & 20.4 & \\
\hline More than twice yearly & 51 & 45.1 & \\
\hline
\end{tabular}

Source: Field Survey, 2018

\subsection{Awareness of Agricultural ProgrammesAired on Radio Stations in the Area}

Respondents' awareness of the various agricultural programmes aired on radio stations reflects the popularity of the telecasts among the respondents. Knowledge of a particular programme and its contents will illicit interest among viewers which could lead to its adoption. The distribution of respondents based on awareness of agricultural programmes aired on radio is presented in Table 2. It reveals that NomaTushenArziki (80.4\%)aired on Gotel FM and Agric Digest Fadama III programmes aired on ABC Yola (63.7\%) are the most common agricultural programmesthat respondents are aware. However, few (46.9\%) of the respondents were aware of $\mathrm{Na}$ Duke TsohonCiniki aired on Fombina FM as depicted in figure 1. This indicates that the respondents are aware of agricultural programmes aired on radio the area. 
Table 2: Distribution of Respondents According to Awareness of Radio Agricultural Programmes

\begin{tabular}{|c|c|c|c|}
\hline Radio stations & Agric Programmes & Frequency & Percentage \\
\hline Gotel AM & NomaTushenArziki & 91 & 80.5 \\
\hline Fombina FM & $\begin{array}{l}\mathrm{Na} \\
\text { TsohonCiniki }\end{array}$ & 53 & 46.9 \\
\hline $\begin{array}{l}\text { Adamawa Broadcasting } \\
\text { Corporation }(\mathrm{ABC}) \text { Yola }\end{array}$ & $\begin{array}{l}\text { Agric Digest, Fadama } \\
\text { III }\end{array}$ & 72 & 63.7 \\
\hline
\end{tabular}

Source: Field Survey, 2018

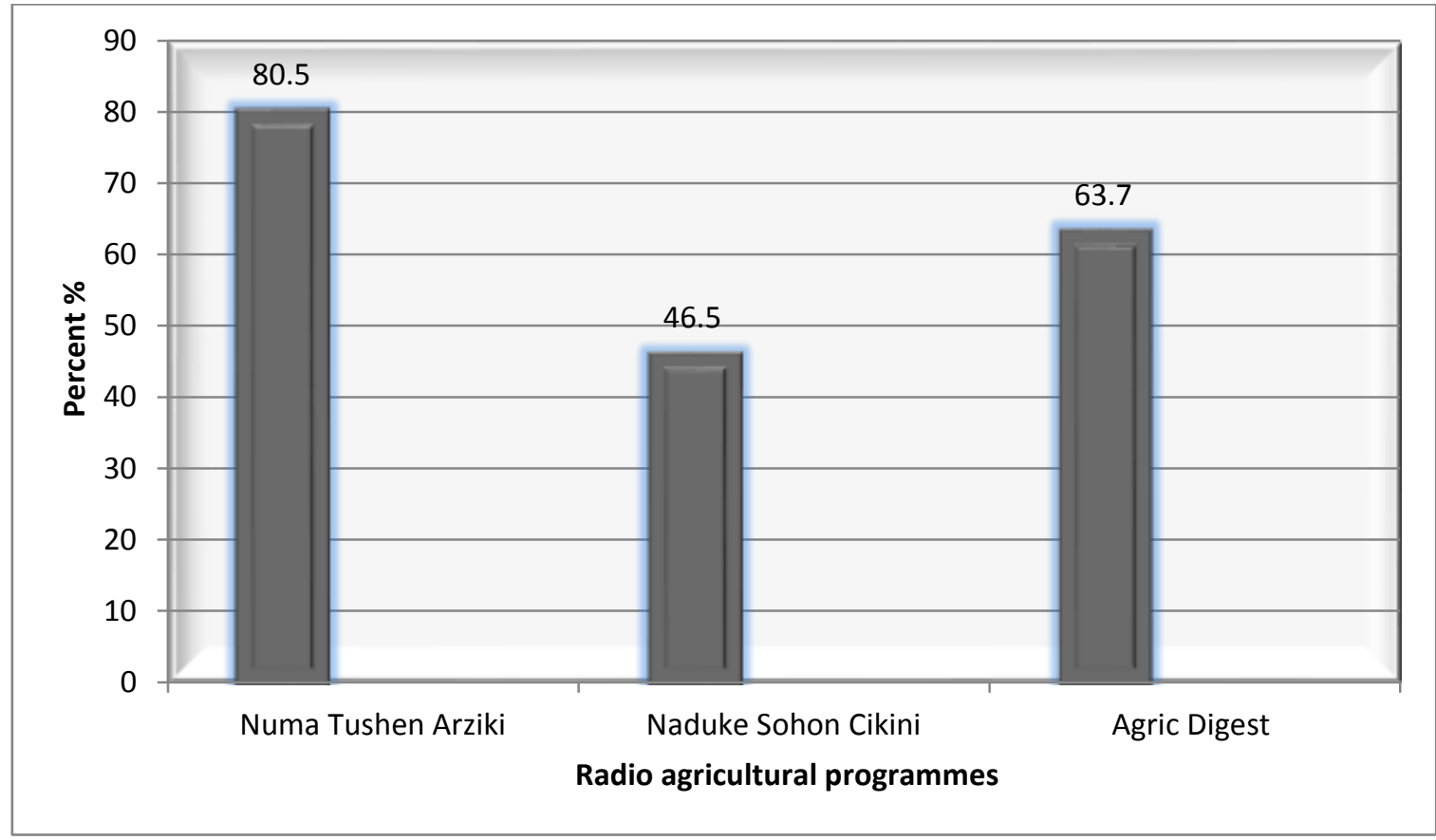

Fig. I Depicted the Percentage level of the respondents on the awareness of radio agricultural programmes in the study area.

\subsection{Agricultural Technologies Aired on Radio Stations in the Area}

For farmers to adopt any technology, they must be convinced that the technology is better than what they are used to. By listening to different agricultural programmes on radio, farmers decide on which technology is accessible, affordable and replicable for them to adopt. The distribution of agricultural technologies that respondents get from radio stations is presented in Table 3. The most common agricultural technologies include; produce marketing (89.4\%), fish production (77.9\%), poultry disease control $(77.7 \%)$, poultry production $(77.0 \%)$, land clearing $(76.1 \%)$, planting methods $(70.8 \%)$ and farm management $(67.3 \%)$. Others include weed control (61.9\%) and weather forecast (61.9\%). However, the remaining information as shown in the table was obtained by only few of the respondents. These include livestock breeding (29.2\%), agro-forestry (27.4\%), fish disease and control (19.5\%),climate distribution (16.8\%) and livestock disease control (15.0\%).

Table 3: Agricultural Technologies Aired on Radio Stations in the Area

\begin{tabular}{lll}
\hline Agricultural Technologies & *Frequency $(\mathbf{n}=113)$ & Percentage \\
\hline
\end{tabular}


International Journal of Advances in Scientific Research and Engineering (ijasre),Vol 5 (7), July-2019

\begin{tabular}{lcc}
\hline Land clearing & 86 & 76.1 \\
Planting methods & 80 & 70.8 \\
Weed control & 70 & 61.9 \\
Livestock breeding & 33 & 29.2 \\
Livestock disease control & 17 & 15.0 \\
Poultry production & 87 & 77.0 \\
Poultry disease control & 81 & 71.7 \\
Fish production & 88 & 77.9 \\
Fish disease and control & 22 & 19.5 \\
Farm management & 76 & 67.3 \\
Weather forecasting & 70 & 61.9 \\
Climate distribution & 19 & 16.8 \\
Produce marketing & 101 & 89.4 \\
Agro-forestry & 31 & 27.4 \\
\hline
\end{tabular}

Source: Field Survey, 2018* Multiple responses

\subsection{Agricultural Information needs of the Farmers from Radio Programmes in the Area}

The agricultural information needs of farmers from radio programmes are presented in Table 4. The distribution shows that majority of the respondents were mostly involved in crop production related activities and this could be attributed to fact that most of them were crop farmers. These include information on weed control (82.3\%), post-harvest losses (79.6\%), planting methods (72.6\%), composting (68.1\%), weather forecasting (51.3\%) and produce marketing (50.4\%). Few respondents needed agricultural information on land clearing (46.9\%), and climate change (38.1\%). Also, majority $(61.1 \%)$ of the respondents needed information on fish production. This could be attributed to the fact that attention is given to fish production by the government as an alternative source of livelihood, additional source of income and a good substitute to meat as a source of protein. Fewer respondents needed information on small ruminant production $(48.7 \%)$, livestock breeding $(38.1 \%)$, livestock disease control $(33.6 \%)$, poultry disease control $(35.4 \%)$, poultry production $(31.9 \%)$ and on beekeeping $(17.7 \%)$.

Table 4: Agricultural Information Need of Farmers from Radio Programmes

\begin{tabular}{lcc}
\hline Items & $\begin{array}{c}\text { *Frequency } \\
(\mathbf{n = 1 1 3})\end{array}$ & Percentage \\
\hline Land clearing & 53 & 46.9 \\
Planting method & 82 & 72.6 \\
Weed control & 93 & 82.3 \\
Livestock breeding & 43 & 38.1 \\
Livestock disease control & 38 & 33.6 \\
Poultry production & 36 & 31.9 \\
Poultry disease control & 40 & 35.4 \\
Fish production & 69 & 61.1 \\
Weather forecasting & 58 & 51.3 \\
Climate change & 43 & 38.1 \\
Produce marketing & 57 & 50.4 \\
Post-harvest losses & 90 & 79.6 \\
Beekeeping & 21 & 17.7 \\
Composting & 77 & 68.1 \\
Small ruminant production & 55 & 48.7 \\
\hline
\end{tabular}

Source: Field Survey, 2018* Multiple responses

\subsection{Factors Influencing the Adoption of Agricultural Production Technologies Aired on Radio Stations in the Area}

The result of the multiple regression analysis used in determining the factors influencing adoption of agricultural production technologies aired on radio stations is presented in Table 5. Four functional forms were tried, namely; linear function, exponential function, semi-logarithm function and double logarithm function. The double logarithm function however, gave the 
best result based on economic, econometric and statistical criteria, hence was chosen as the lead equation. The regression result is specified thus;

$\log \mathrm{Y}=-0.951+0.222 \ln \mathrm{x}_{1}+0.438 \ln \mathrm{x}_{2}+0.393 \ln \mathrm{x}_{3}+0.117 \ln \mathrm{x}_{4}+0.645 \ln \mathrm{x}_{5^{-}} 0.144 \ln \mathrm{x}_{6}$

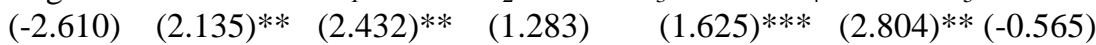

$-0.008 \ln \mathrm{x}_{7^{-}}-0.318 \ln \mathrm{x}_{8}+0.331 \ln \mathrm{x}_{9}+0.324 \ln \mathrm{x}_{10}$

$(-0.009) \quad(-1.473) \quad(1.540) \quad(2.055) * *$

Figures in parentheses are the corresponding t-values

*** Significant at $1 \%$ level; ** Significant at 5\% level *Significant at $10 \%$ level

$\mathrm{R}^{2}=0.754$

The result of the analysis as shown on Table 5 reveals that four of the ten explanatory variables used in the analysis were significant at varying levels. These include coefficients of age $\left(\mathrm{x}_{1}\right)$, education $\left(\mathrm{x}_{2}\right)$, farm size $\left(\mathrm{x}_{5}\right)$ and radio ownership $\left(\mathrm{x}_{10}\right)$. The coefficient of multiple determination $\left(\mathrm{R}^{2}\right)$ is 0.754 implying that $75.4 \%$ of the change in the adoption rate of agricultural production technologies aired on radio is explained by the independent variables used in the model, thus, the variables have fitted well into the model.

The coefficient of $\mathrm{X}_{1}$ (age of the farmers) was positive and statistically significant at 0.05 level. This implies that as farmers becomes older, the adoption of agricultural production technologies aired on radio increases. As farmers become older,they gained more experienced in farming, and their quest to adopt technologies that will increase agricultural productivity also increases. Thus, they are likely to patronize agricultural programmes on radio that appeals to their production needs.Educational level enhances the ability of the farmers to derive, decode and evaluate useful information for agricultural production. The coefficient of education $\left(\mathrm{X}_{2}\right)$ was estimated at 0.438 and statistically significant at 0.05 level. This implies that as farmers' level of education increasesthe adoption of agricultural production technologies aired on radio increases. Educated farmers are expected to be more efficient in understanding and obtaining new technologies in a shorter period of time than the uneducated farmers. The coefficient of farm size $\left(\mathrm{X}_{5}\right)$ was estimated at 0.645 and statistically significant at 0.01 level, implying that the larger the farm size the higher the tendency of farmers to adopt agricultural (crop) production technologies aired on radio. Farmers with larger farm sizes are more likely to have more opportunities to learn about an innovation, have more incentive to adopt it, and are able to bear risks associated with early adoption than those with smaller farm sizes. The coefficient of ownership of radio $\left(\mathrm{X}_{10}\right)$ was positive and also statistically significant at 0.05 level.This implies that owning a radio set will increase the likelihood of farmers to adopt improved agricultural technologies disseminated via radio. When the programme timing favours the farmer, the tendency is for the farmer to always tune in to the programme.

Table 5: Result of Multiple Regression Analysis

\begin{tabular}{lcccc}
\hline Variable & Parameter & Coefficient & Standard-error & t-ratio \\
\hline Constant & $\beta_{0}$ & -0.951 & 0.36451 & $-2.610^{* *}$ \\
Age $\left(\mathrm{X}_{1}\right)$ & $\beta_{1}$ & 0.222 & 0.1039 & $2.135^{* *}$ \\
Education $\left(\mathrm{X}_{2}\right)$ & $\beta_{2}$ & 0.438 & 0.1801 & $2.432^{* *}$ \\
Household size $\left(\mathrm{X}_{3}\right)$ & $\beta_{3}$ & 0.393 & 0.3063 & 1.283 \\
Farming experience $\left(\mathrm{X}_{4}\right)$ & $\beta_{4}$ & 0.117 & 0.0721 & 1.625 \\
Farm size $\left(\mathrm{X}_{5}\right)$ & $\beta_{5}$ & 0.645 & 0.2301 & $2.804^{* * *}$ \\
Extension contact $\left(\mathrm{X}_{6}\right)$ & $\beta_{6}$ & -0.144 & 0.2548 & -0.565 \\
Sex $\left(\mathrm{X}_{7}\right)$ & $\beta_{7}$ & -0.008 & 0.8889 & -0.009 \\
Credit access $\left(\mathrm{X}_{8}\right)$ & $\beta_{8}$ & -0.318 & 0.2159 & -1.473 \\
Membership of association $\left(\mathrm{X}_{9}\right)$ & $\beta_{9}$ & 0.331 & 0.2149 & 1.540 \\
Radio ownership $\left(\mathrm{X}_{10}\right)$ & $\beta_{10}$ & 0.374 & 0.1820 & $2.055^{* *}$ \\
\hline
\end{tabular}


$\mathrm{R}^{2}=0.754$

Source: Field survey, 2018

*** Significant at $1 \%$ level; ** Significant at $5 \%$ level

\section{CONCLUSION}

Agricultural programmes aired on radio help to sensitize and educate farmers about improved agricultural practices. This medium serve as an effective tool in creating awareness on improved agricultural practices among farmers. The study examined the role of agricultural radio programmes in the adoption of agricultural production technologies among farmers in Girei Local Government area of Adamawa State. The study revealed that most of the farmers were educated and also in their economically active age. Many of the respondents are aware of agricultural programmes aired on radio in the area, especially agricultural programmes aired on Gotel FM and Adamawa Broadcasting Corporation. The common agricultural programmes aired on radio among others include produce marketing, fish production, poultry disease control, land clearing and planting methods. On the information needs of the farmers, the study identified mostly crop production related activities as the ones mostly needed by the farmers. On the factors responsible for adoption of agricultural technologies aired on radio, the study identified age of the farmers, level of education, farm size and radio ownership are significantly influencing the adoption of agricultural production technologies aired on radio in the area.

\section{RECOMMENDATIONS}

Based on the research findings from this study, the following recommendationsare preferred.

i) The importance of education in the adoption of improved farming technologies cannot be over emphasized. Farmers should be sensitized on the need to have some level of formal education to enable them make better use of any new technology aired on radio.

ii). The radio stations should give more slots to agricultural pragrammes so as to create awareness in farmers so that they can adopt improved farming technologies.

iii). The programme content developers in broadcast media should incorporate and create opportunities for effective viewers' participation through feedbacks. This will help farmers ask questions that relate to their agricultural production activities.

iv). Training and re-training of presenters and producers should be on a regular basis, as this will enhance their performance and quality presentation of agricultural radio programmes.

\section{CONFLICT OF INTREST STATEMENT}

The authors declared no interest on the research work

\section{ACKNOWLEGEMENT}

The authors would like to acknowledge the effort of the management of all the Radio Stations for providing necessary information required for the success of the research work.Likewise, the participatory farmers in the research for their time. Above all, to those whose works were cited we highly acknowledged.

\section{REFERENCES}

[1]. Stefano, L.A., Hendriks, S. L., Stilwell, C. and Morris, C. (2005). Printed Information Needs of Small-Scale Organic Farmers in Kwazulu-Natal.Libri, pp. 55: 56-66. 
[2]. LEISA. (2002). Low External Input for Sustainable Agriculture Magazine on Low External Input for Sustainable Agriculture.ChangingInformation Flow. Leusden. The Netherlands, 18(4):15-20

[3]. Oladele, O. J. (1999). Analysis of the Institutional Research - Extension Farmers Linkage System in South Western Nigerian. An Unpublished Ph.D Thesis in the Development of Agricultural Extension and Rural Development, University of Ibadan, Nigeria (Internet).

[4]. Agboola, A. T. (2000). Rural Information Supply and Nigerian Agricultural Libraries.Rural Libraries, 20(2): 29-37.

[5]. Kaye, D. (1995). The Importance of Information.Library Management, 16(5), pp. 6-25.

[6]. Opara, U. N. (2008). Agricultural Information Sources Used by Farmers in Imo State, Nigeria.Information Development, SAGE Publications, 24(4): 289-295.

[7]. Nazari, M.R and Salleh, M. H. (2011). The Role of Television in the Enhancement of Farmers' Knowledge.African Journal of Agricultural Research, 6(4): 931-936

Educational

[8]. Chapman, R. (2003). Rural Radio in Agricultural Extension: The example of Vernacular Radio Program 'Son Soil and Water Conservation in Northern GHANA. Network paper 127:15.

[9]. Ozowa, (1995) Quarterly Bulletin of the International Association Information Specialist, IAALD/CABL. 40(1)

[10]. Adebo, G.M. and Ewuola, S.O. (2005). Impact of Micro Credit and Effective Communication on Women's income.Journal of Agricultural Extension, 8 (1): 47 - 154 (Nigeria)

[11]. Adebayo, A.A. (1999). Climate I and II.Adebayo, A.A. and Tukur, A.L (eds.), Adamawa State in Map.Department of Geography, Federal University of Technology, Yola.Paraclete publishers, Yola. 20-26 b

[13]. FAO (1992). Population Education and Nutrition: Version for Africa, Rome.

[12]. NPC (2006): National Population Commission, Federal Office of Statistics. Census 2006.

[14]. Njoku,J. I. K. (2016). Effectiveness of Radio -Agricultural farmers Programmes in Technology Transfer among Rural Farmers in Imo State,Nigeria. Net Journal of Agricultural Science, 4(2):22-28 